Albert Przemysław Bażyk OP

\title{
Krata podwójna: próba opisu wydarzeń przyszłych za pomocą narzędzi logicznych
}

Arystoteles, twórca logiki w klasycznym jej rozumieniu, dostrzegał jej braki w związku z wydarzeniami mającymi się wydarzyć w przyszłości. Chęć znalezienia odpowiedzi na nurtujące umysły filozofów pytania stawiała logików przed niełatwym zadaniem, a mianowicie znalezieniem języka mogącego posłużyć do opisania tych zdań, wobec których podejście klasyczne zdaje się nie spełniać swoich funkcji.

W niniejszym artykule chciałbym przybliżyć współcześnie rozwijaną koncepcję logiki czterowartościowej opartej na bazie kraty $^{1}$ podwójnej FOUR. Obecnie uznaje się ją za koncepcję najbardziej zbliżoną do takiej, za pomocą której dałoby się opisać każde zdanie wyrażone w języku naturalnym. Logika oparta na

\footnotetext{
${ }^{1}$ Definicja kraty: Zbiór L uporządkowany przez relację porządku nazywa się kratą (ang. lattice) względem tej relacji, jeśli każdy dwuelementowy podzbiór L ma oba kresy: górny i dolny. Gdy L jest kratą, $x, y \in$ $L$, to kres dolny zbioru $\{\mathrm{x}, \mathrm{y}\}$ oznaczamy $x \wedge y$, zaś kres górny tegoz zbioru przez $x \vee y$ i zwiemy odpowiednio iloczynem i sumą $x$ i $y$. za: <http://www.matematyka.pl/135410.htm>, 27.09.2012
} 
podwójnej kracie pozwala nam na pogłębienie rozważań na temat wydarzeń przyszłych.

W pierwszej części zaprezentuję klasyczną logikę, opisując schemat jej działania oraz narzędzia, które wykorzystuje (1.1.). Następnie spróbuję pokazać to, czego logice klasycznej może brakować dla pełniejszego opisu naszej rzeczywistości (1.2.). Na końcu przedstawię kilka stanowisk, które starają się wyjść naprzeciw tym brakom i szukają na nie odpowiedzi.

W kolejnej części przejdę do prezentacji samej teorii krat, poprzez omówienie jej podstawowego języka i zjawisk, na których ta teoria zaczyna się tworzyć (2.1. oraz 2.2.) i które doprowadzą nas do opisu logiki opartej na podwójnej kracie FOUR (2.3.).

Na końcu postaram się zestawić teorię krat z innymi koncepcjami filozoficzno-logicznymi, usiłującymi opisać kwestie zdarzeń przyszłych. Zamierzam, w porównaniu z różnymi strukturami, pokazać większą wiarygodność, czy poprawność systemu logicznego, jakim jest krata FOUR.

Ze względu na braki w literaturze polskojęzycznej, dotyczącej tego tematu, w swojej pracy jako bazę wykorzystuję pozycję Krystyny Misiuny pt. Pojęcie prawdy w języku naturalnym. Większość pozostałej literatury, wykorzystanej w tej pracy rekonstrukcyjnej, stanowią artykuły anglojęzyczne, które, jak na bardzo krótki okres badań nad tą strukturą, są bogatym źródłem wiadomości na temat osiągnięć współczesnej logiki wielowartościowej, będącej $\mathrm{w}$ trakcie nieustannego, dynamicznego rozwoju.

\section{Logika klasyczna i jej braki}

\subsection{Logika dwuwartościowa - klasyczne ujęcie prawdy i fałszu; narzędzia logiki klasycznej}

Fundamentem logiki klasycznej wydaje się być założenie, że każdemu zdaniu wyrażonemu w języku naturalnym możemy nadać wartość logiczną prawdy lub fałszu. Zdania poddajemy analizie ze względu na schemat logiki klasycznej, który mówi, że „zdanie 
$p$ jest prawdziwe wtedy i tylko wtedy, gdy zachodzi to, co zdanie $p$ wyraża" ${ }^{2}$. Założenie badające tę prawdziwość bądź fałszywość zdania zwykło się nazywać zas ad ą dwuwartościowości, w której to znajdujemy zarówno przedmiot oraz obszar zakresowy działania logiki klasycznej ${ }^{3}$. Grzegorz Malinowski, we wstępie do swojej książki Logiki wielowartościowe, wprowadza nas do rozważań o tychże logikach, skupiając się na istocie klasycznego podejścia do logiki. Stwierdza on słusznie, że podstawowymi systemami logiki klasycznej są klasyczny rachunek zdań (KRZ) i klasyczny rachunek predykatów (KRP), zwany inaczej rachunkiem kwantyfikatorów ${ }^{4}$. Oba te systemy umożliwiają zapis zdania, które rozpatrujemy $\mathrm{w}$ aspekcie jego $\mathrm{prawdzi-}$ wości czy fałszy wości za pomocą symboli, z tym że KRP, korzystając z symboli KRZ, dodaje do nich kwantyfikatory nazwowe, umożliwiające pełniejszą analizę tych zdań.

Dla głębszego zrozumienia klasycznego ujęcia praw d y i fa łs z u, wydaje się konieczne zwrócenie uwagi na cały system, jaki wypracowała logika klasyczna na przestrzeni wieków, a który to system ma służyć opisowi zdań, które poddajemy właśnie tej prawdziwościowej ocenie. Jeśli chodzi o KRZ, jest to nic innego, jak najbardziej podstawowy system, za pomocą którego zapisujemy jakieś zdanie w omawianej logice dwuwartościowej. Służą temu spójniki negacji, implikacji, a lternatywy, koniunkcji i równoważności oraz nawiasy. Dane zdanie, wyrażone w klasycznym rachunku zdań, musi po prostu zawierać określony spójnik, dzięki któremu zapis zdania będzie można sformalizować np. za pomocą tabeli prawdziwościowej, w której zdaniu prawdziwemu przypisujemy wartość (1), zdaniu zaś fałszywemu odpowiednio wartość $(0)^{5}$. Stąd to właśnie otrzymujemy nazwę logiki dwuwartościowej.

\footnotetext{
${ }^{2}$ K. Misiuna, Pojęcie prawdy $w$ jezyku naturalnym, Warszawa 2003, s. 99.

${ }^{3}$ Zob. G. Malinowski, Logiki wielowartościowe, Warszawa 1990, s. 9.

${ }^{4}$ Tamże.

${ }^{5}$ Zob. tamże, s. $13-14$.
} 
Gdy prowadzimy rozważania dotyczące zarówno KRZ, jak i KRP, nie sposób ominąć zjawiska t a u t o lo g i c z nośc i, którym określamy „formuły będące schematami wyłącznie zdań prawdziwych" ${ }^{6}$. Są to na przykład: praw o podwójnej negacji, prawo wyłączonego środka czy zasada sprzeczności. Stanowią one prawa logiki, których stosowanie ma na celu uniknięcie wyrażania sprzecznych, czy wręcz absurdalnych twierdzeń.

Z tautologicznością zdań ściśle związane jest także zjawisko bardzo istotne dla logiki klasycznej, a mianowicie a ks jo mat. $\mathrm{Z}$ definicji musi on być tautologią i służyć ma nam jako narzędzie, gdy mamy do czynienia z regułami wnioskowania, takimi jak: reguła podstawiania $(\mathrm{RP})$ i reguła odrywania $(\mathrm{RO})^{7}$. W kontekście tych rozważań, aksjomaty służą nam do badania tautologiczności bardzo skomplikowanych zdań, wyrażonych za pomocą KRZ czy KRP, które korzystają ze zjawiska a ksjomaty c zności.

Jeżeli zaś zwrócimy uwagę na klasyczny rachunek predykatów (KRP), to zauważymy, że różni się on nieco od KRZ, jest bowiem wzbogacony dodatkowo o z mienne nazwowe (określające nazwy poszczególnych indywiduów), p redykaty (funkcje zdaniotwórcze od argumentów nazwowych) i kwantyfikat ory ( „dla każdego” oraz „istnieje”).

Skrótowa analiza podstawowych pojęć i terminów, za pomoca których logika klasyczna pozwala nam wyrazić prawdziwość albo fałszywość zdania wyrażonego w języku naturalnym, posłuży lepszemu zrozumieniu zastosowania i rozszerzenia logiki klasycznej we współczesnych logikach, zwanych d e w i a n t ny mi.

\subsection{Braki logiki klasycznej}

Grzegorz Malinowski w cytowanej już pracy o Logikach wielowartościowych zauważa, że sam Arystoteles (IV wiek p.n.e.) zastanawiał się nad zdaniami wyrażającymi zdarzenia przyszłe

\footnotetext{
${ }^{6}$ Tamże, s. 15.

${ }^{7}$ Zob. tamże, s. 18.
} 
przypadkowe, zwane future contingents. Z refleksjami tymi możemy spotkać się w rozdziale IX Hermeneutyki Arystotelesa ${ }^{8}$, gdzie autor prowadzi rozważania nad zdaniem przyszłym:

Co się tyczy tego, co jest i co było, twierdzenia lub przeczenia muszą być prawdziwe bądź fałszywe. Co się zaś tyczy twierdzeń o ogółach branych ogólnie, to zawsze jedno z nich musi być prawdziwe, a drugie fałszywe. (...) Co się znów tyczy zdań szczegółowych i dotyczących przyszłości, sprawa przedstawia się inaczej. (...) Gdyby twierdzenie, że coś jest białe i wielkie, było prawdziwe, to obydwie te cechy musiałyby przysługiwać, a jeżeli prawdą jest, że będą przysługiwać jutro, to muszą przysługiwać jutro. Gdyby natomiast coś nie mogło się jutro zdarzyć i nie mogło nie zdarzyć, to nie miałby miejsca przypadek. Za przykład niech posłuży bitwa morska: ani by się jutro odbyła, ani nie odbyła ${ }^{9}$.

Łatwo można tu dostrzec trudności z określeniem p r a w d z i w o śc i czy fałs z y wo ści takiego stwierdzenia, dlatego Malinowski przytacza sugestię Arystotelesa na temat wytworzenia się tzw. trzeciej kategorii logicznej ${ }^{10}$.

Logika klasyczna w swoich rozważaniach napotyka na jeszcze dwie bardzo ważne kwestie. Po pierwsze, spójniki występujące w KRZ sa jedynie idealizacjami niektórych spójników z języka potocznego. Co więcej, implikacja, jako formalny reprezentant okresu warunkowego, ma specyficzne warunki prawdziwości: nie

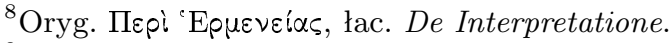

${ }^{9}$ Arystoteles, „Hermeneutyka”, IX, 18b, [w:] Arystoteles, Dzieła Wszystkie, przeł. K. Leśniak, t. I, Warszawa 1990, s. 75-76.

W oryginale tekst mówiący o wydarzeniu przyszłym, jakim dla Arystotelesa

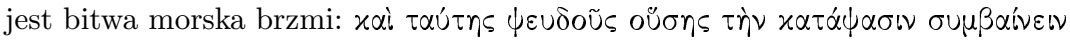

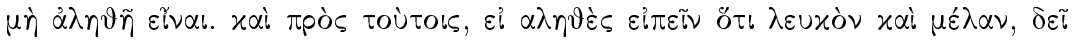

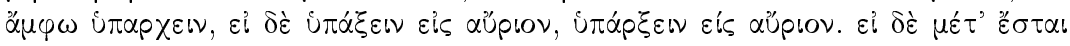

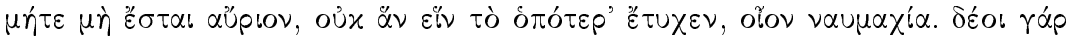

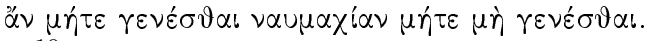

${ }^{10}$ Zob. G. Malinowski, dz. cyt., s. 10.
} 
uwzględnia zależności treściowej pomiędzy zdaniami, które łączy ${ }^{11}$. Dla unaocznienia można przytoczyć zdanie: „Jeżeli jutro będzie ładna pogoda, to mój wujek ma dwie córki". W takim wyrażeniu bardzo istotny jest jego sens, gdyż, wypowiadając jakieś zdanie, powinniśmy przedstawić dane w sposób spójny i zrozumiały. Drugim problemem jest sytuacja, w której kwantyfikatory w KRP generują sztuczne parafrazy dla wyrażeń języka potocznego. Kwantyfikator egzystencjalny sugeruje istnienie obiektów tworzących zakres zmiennej związanej tym kwantyfikatorem. Z kolei zdania z kwantyfikatorem uniwersalnym są prawdziwe nawet wówczas, gdy nie istnieją obiekty spełniające poprzednik implikacji ${ }^{12}$. Tutaj możemy jako ilustracje podać zdanie: „Wszystkie istniejące krasnoludki mają nie więcej jak $100 \mathrm{~cm}$ wzrostu". Przykład ten pokazuje absurdalność poprzednika implikacji tegoż zdania, ponieważ, jak powszechnie wiadomo, krasnoludki nie istnieją, zaś w świetle logiki klasycznej zdanie to mogłoby być prawdziwe.

\subsection{Poszukiwania innych rozwiązań}

Po wielu intelektualnych, toczących się na przestrzeni wieków debatach, których przedmiotem było Arystotelesowskie stwierdzenie o zdarzeniach przyszłych przypadkowych, przełomowym momentem staje się rok 1920 i osoba Jana Łukasiewicza, powszechnie nazywanego ojcem logiki trójwartościowej. Punktem wyjścia jego dokonań jest krytyka poglądu Arystotelesa, który twierdził że zasada sprzeczności (bardziej rozpowszechniona pod nazwą ,zasady niesprzeczności”), postaci $\neg(p \wedge \neg p)$ jest oczywista sama przez się ${ }^{13}$. Ta refleksja, podjęta między innymi przez Łukasiewicza, zmusiły logików do stawiania pytań dotyczących obecnego kształtu i zastosowania logiki.

${ }^{11}$ Zob. K. Bach, „Language, Logic and Form”, [w:] D. Jacquette, A Companion to Philosophical Logic, Oxford 2002, s. 51-73.

12 Zob. K. Bach, „Language, Logic and Form”, [w:] D. Jacquette, A Companion to Philosophical Logic, Oxford 2002, s. 51-73.

${ }^{13}$ Dziełem Łukasiewicza w którym analizuje i krytykuje podejście Arystotelesa do zasady niesprzeczności jest $O$ zasadzie sprzeczności u Arystotelesa. 
Jednak gdy zastanawiamy się nad tym, czy logiki wielowartościowe powstały jako odpowiedź na niedoskonałości logiki klasycznej, warto postawić sobie pytanie, czy problem nie dotyczy raczej kwestii istnienia tylko jednego poprawnego systemu logicznego; czy wyłącznie logika klasyczna jest słuszna, a może powinna ją ostatecznie zastąpić logika wielowartościowa? Na te i inne pytania stara się udzielić odpowiedzi Susan Haack w swoim artykule Niektóre pytania metafizyczne i epistemologiczne dotyczace logiki, gdzie w części poświęconej zagadnieniom metafizycznym logiki wprowadza podział na trzy stanowiska, które można zajmować w odniesieniu do przedstawionych wyżej zagadnień. A mianowicie:

1. monizm - stanowisko zakładające poprawność tylko jednego systemu logicznego;

2. pluralizm - dopuszczalna jest wielość stanowisk wobec poprawności logicznego rozumowania;

3. instrumentalizm - niedopuszczalne jest użycie terminu „poprawność", gdyż nie mamy do czynienia z żadnym podejściem, które mogłoby wskazywać na „poprawność” którejś $\mathrm{z} \operatorname{logik}^{14}$.

Autorka, w komentarzu do zaprezentowanego podziału, zaznacza, w jaki sposób należy rozumieć różnicę pomiędzy poprawnością (prawdą logiczną) uogólnioną jako system i rozpatrywaną pozasystemowo $^{15}$.

System logiczny jest poprawny, jeżeli rozumowania formalne, które są ważne w tym systemie, odpowiadają rozumowaniom nieformalnym, które są poprawne pozasystemowo, a formuły prawidłowo zbudowane, logicznie prawdziwe w tym sensie, odpowiadaja twierdzeniom logicznie prawdziwym $\mathrm{w}$ sensie pozasystemowym ${ }^{16}$.

14 Zob. S. Haack, „Niektóre pytania metafizyczne i epistemologiczne dotyczacce logiki", [w:] Filozofia logiki, red. J. Woleński, Warszawa 1997, s. 237.

15 Zob. tamże.

16 Tamże, s. 237-238. 
Na tym etapie rozważań warto uwypuklić różnicę pomiędzy rozszerzen i a mi logiki klasycznej oraz jej d e w i a cjami. Gdy spojrzymy na założenia logiki modalnej, to stwierdzimy, że istnieją $\mathrm{w}$ logice pewne sposoby rozumowania oraz takie prawdy, których nie jesteśmy w stanie zaprezentować przy pomocy narzędzi udostępnionych nam przez logikę klasyczną. Nadto logika modalna stwierdza, w zgodzie z własną analizą, że klasyczne podejście sprawdza się tylko w pewnym zakresie, przy widocznych brakach tej metody. Z kolei założenia logiki trójwartościowej radykalnie odrzucają faktyczną poprawność logiki klasycznej ${ }^{17}$.

W świetle tych rozważań zauważymy, że monistyczne podejście bliższe jest logikom modalnym, stawiającym problem prawdziwości systemu w kategoriach całkowicie skrajnego podejścia do zagadnień - możliwa jest tylko jedna z wersji logiki. Przyjmując jedną wersję, należy odrzucić tę drugą. W koncepcji pluralistycznej zaś odnajdzie się także logik wielowartościowy, który nie odrzuca całkowicie logiki klasycznej poprzez zastąpienie jej nowym tworem. Jednakże uzupełnia ją o pewne, jak się wydaje, pomocne systemy, pozwalające patrzeć na konkretne zdanie w szerszej perspektywie - np. W kontekście zdań przyszłych.

W kolejnych etapach badań logicznych pojawiały się nowe, oryginalne koncepcje, proponujące nowe spojrzenie na logike od strony jej ewentualnej wielowartościowości. Warto w tym miejscu wymienić kilka z nich w formie przykładu, a mianowicie: logiki Posta, trójwartościowość Kleenego i Boczwara, logiki modalne Lewisa (tzw. S4 i S5), zbiory rozmyte i logika Zadeha ${ }^{18}$. Inną metodą, wytyczającą nowy szlak, jest zastępująca całkowicie logikę klasyczną logika modalna.

Następnym zagadnieniem wartym analizy jest zjawisko konieczności i możliwości danego zdarzenia. Są to niewątpliwie fundamentalne kwestie, gdy jest mowa o logice modalnej, która w przeciwieństwie do wielowartościowej, chcącej uzupełnić logikę

\footnotetext{
${ }^{17}$ Zob. tamże, s. 238.

${ }^{18}$ Więcej o wspomnianych koncepcjach można odnaleźć m. in. w przywoływanym już dziele G. Malinowskiego: Logiki wielowartościowe.
} 
klasyczną, ma być czymś całkowicie nowatorskim dla świata logiki. Najprościej różnicę między koniecznością a przypadkowością ujmuje zdanie, że „prawda konieczna to taka, która nie mogłaby być inna, a prawda przypadkowa mogłaby być inna" ${ }^{19}$. Formalnie zapis prawdy koniecznej przedstawia się jako $\square X \leftrightarrow \neg \diamond \neg X$ (X jest konieczne wtedy i tylko wtedy, gdy nie możliwe jest „nie X”), zaś możliwej jako $\diamond X \leftrightarrow \neg \square \neg X$ (X jest możliwe wtedy i tylko wtedy, gdy nie jest konieczne „nie X”).

Reasumując w części niniejszej zostały pokazane braki występujące w logice klasycznej, która - ze względu na przedstawione luki - nie pozwala na głębszą analizę zdań wyrażonych za pomocą języka naturalnego we wszelkich możliwych aspektach, w tym we wspomnianych zdarzeniach przyszłych, wobec których logice klasycznej brakuje stosownych narzędzi. Niedoskonałości te pozostawiły niedosyt $\mathrm{w}$ umysłach wielu filozofów analitycznych, którzy w XX w. zaproponowali liczne teorie, mogące posłużyć do wyrażenia niemalże każdego zdania z języka naturalnego. W ten właśnie sposób powstała także logika czterowartościowa na bazie podwójnej kraty FOUR.

\subsection{Zjawisko nieostrości}

Jednym z systemów, dla którego logika klasyczna wraz ze swoimi narzędziami jest niewystarczająca, jest stosunkowo nowa koncepcja logiki czterowartościowej, opartej na bazie kraty FOUR. Zanim jednak poddamy ją głębszej analizie, warto zwrócić uwagę na pewne zjawisko, z którym mamy do czynienia w naszym postrzeganiu. Można mianowicie bronić teorii, że logika dwuwartościowa ze swoim „biało-czarnym” podejściem nie zawsze jest dobrym narzędziem, gdyż nie dopuszcza właśnie takich zjawisk jak pojęcie nieostrości.

Zjawisko to opisuje pewien eksperyment, w którym obserwatorowi podaje się do oglądania serię barwnych przedmiotów, których

\footnotetext{
${ }^{19}$ S. Haack, „Logika modalna”, [w:] Filozofia logiki, red. J. Woleński, Warszawa 1997, s. 183.
} 
kolor odpowiednio zmienia się - na przykład od czerwonego do różowego. Badane osoby prosi się także o zaznaczenie na skali liczbowej pewności co do tego, jak bardzo są przekonani, jaki widzą kolor. Najwyższy stopień pewności jest zauważalny na krańcowych punktach tabeli, czyli w momentach, gdy pokazywany przedmiot miał niewątpliwie kolor czerwony lub różowy ${ }^{20}$. Na tej podstawie możemy wyciągnąć wniosek, że nie występuje ostra granica między przedmiotami, które kwalifikujemy jako „czerwone”, a tymi, które ujmujemy jako „nie-czerwone”. Fakt ten według Krystyny Misiuny możemy rozumieć dwojako: albo umysł ludzki jest tak ułomny, że nie dostrzega tego rozróżnienia i niuansów barw, albo rozumienie i zakres predykatu „,jest czerwone” zostały wadliwie zdefiniowane ${ }^{21}$. W języku naturalnym możemy spotkać się z podobnym problemem, gdy chcielibyśmy czysto oglądowo, bez liczenia, ocenić, że osoba posiadająca $n$ włosów na głowie jest łysa, a osobę mająca ich już $(n+1)$ nie uznamy za łysą ${ }^{22}$. Jak to trafnie określa Misiuna:

ani nasza lepsza znajomość języka, ani też nasza lepsza wiedza dotycząca świata nie może odsłonić ukrytej ostrej granicy zakresu predykatu nieostrego, ponieważ granica taka po prostu nie istnieje, o ile użytkownicy języka naturalnego nie wyznaczac jej arbitralnie w aktach komunikacyjnych ${ }^{23}$.

W kontekście rozważań na temat zjawiska nieostrości warto zwrócić uwagę na semantykę superwaluacyjną, która prowadzi nas do teorii, że predykaty nieostre moga być dowolnie precyzowane. Przecież to właśnie każda precyzacja wyznacza owe ostre granice naszym nieostrym predykatom. W takim sensie mamy do czynienia z wartościowaniem formuły nieostrej w oparciu o jakąś subiektywną precyzację, która to owe wartościowanie niejako

20 Zob. M. Changizi, „Vagueness and computation”, Acta Analytica, 14 (1999), s. 39-45.

21 Zob. K. Misiuna, dz. cyt., s. 121.

22 Przykład z „osobą łysą” podaję za: K. Misiuna, dz. cyt., s. 122.

${ }^{23}$ Tamże. 
z góry narzuca. Jednak „bronią się” w tej teorii zdania, dla których klasyczna wartość logiczna pozostaje niezmienna. Są one zwane zdaniami superprawdziwymi (gdy ich wartość logiczna wynosi „1") oraz superfałszywymi (gdy wartość logiczna wynosi „,0") ${ }^{24}$.

Wspomniane nieostre predykaty nierzadko sprawiają nam wiele trudności. Misiuna odwołuje się w swojej pracy do aktów komunikacyjnych, które z kolei definiuje Michael Tomasello jako coś mającego miejsce wtedy, gdy osoba mówiąca używa słów, aby zwrócić uwage słuchacza na dany przedmiot lub zjawisko znajdujące się w świecie ${ }^{25}$. Aktem komunikacyjnym w przykładzie Misiuny jest zdanie: „a jest różowy”, z odniesieniem do istniejącego realnie przedmiotu, będącego jednak na pograniczu kolorów różowego i czerwonego. Właśnie za pomoca tej wypowiedzi osoba mówiąca jest w stanie zwrócić uwagę słuchacza na przedmiot $a$. Jednak nie byłaby w stanie tego zrobić, gdyby użyła komunikatu „a jest czarny", gdyż jest to kolor zupełnie odmienny od różowego, nie nastręczający problemów z jego odróżnieniem. W tych rozważaniach natomiast bardzo istotne jest zwrócenie uwagi na tę nieostrość, która mogłaby być spowodowana inną interpretacją tegoż aktu komunikacyjnego. A w przypadku takiej nieostrości może wystąpić właśnie druga interpretacja, która będzie miała miejsce, gdy słuchacz usłyszy komunikat, że „a jest czerwony”. Dzięki takiemu komunikatowi mówiący jest także w stanie zwrócić uwage słuchającego na przedmiot $a$. Tomasello zauważa, że decyzja co do wyboru zdania przez mówiącego zależy od czysto pragmatycznego punktu widzenia, jakim może być zainteresowanie słuchacza ${ }^{26}$.

W następnym kroku trzeba wyobrazić sobie dwie osoby mówiące, $A$ i $B$, które wprowadzamy jako niezależne do naszego eksperymentu. Każda z tych osób wypowiada inny wariant komunikatu. Za Misiuną przyjmijmy, że $A$ mówi zdanie: „a jest

\footnotetext{
${ }^{24}$ Zob. tamże, s. $122-123$.

${ }^{25}$ Zob. M. Tomasello, „Reference: intending that others jointly attend”, Pragmatics and Cognition, 6 (1998), s. 236.

${ }^{26}$ Zob. M. Tomasello, „The human adaptation for culture”, Annual Reviews of Anthropology, 28 (1999), s. 517.
} 
różowy”, zaś $B$ zdanie: „a jest czerwony”. Słuchacz natomiast słyszy obydwa te komunikaty, najpierw od osoby $A$, następnie od osoby $B$. Osoba, po usłyszeniu tych informacji, posiada dwa komunikaty: „a jest różowy” oraz „a jest czerwony”. Po refleksji, słuchacz (w tym momencie już obserwator) dochodzi do przekonania, że obydwa te komunikaty są ze sobą sprzeczne, więc przedmiot $A$ musi być zdefiniowany jako czerwony, ale wtedy nie jest różowy, albo jest różowy, a nie jest czerwony. W sumie daje to obserwatorowi już dwie pary zdań ze sobą sprzecznych: „a jest różowy” i „a nie jest różowy” oraz „a jest czerwony” i „a nie jest czerwony". Nie możemy jednak o tych zdaniach powiedzieć, że tylko jedno z nich jest prawdziwe, gdyż nie są to zdania, w których jasno widzimy, na przykład, prawdziwość pierwszego i fałszywość drugiego (jak w przykładzie: „kwadrat ma cztery boki” oraz „kwadrat ma sześć boków"). Analiza zdań odnoszących się w jakiś sposób do barw, sprawia wiele trudności, gdyż ich nieostrość stoi na przeszkodzie w próbie jednoznacznego określenia, czy przedmiot a jest „czerwony” czy „różowy”, a to dlatego, że poprawne określenie koloru tego przedmiotu znajduje się na granicy wspomnianych pojęć. Na podstawie tego przykładu ${ }^{27}$, można określić kilka warunków teorii pojęć nieostrych, a mianowicie:

1. Zasada dwuwartościowości nie obowiązuje dla języka nieostrego;

2. Zdanie „Istnieje liczba $n$ taka, że człowiek, który ma $n$ włosów na głowie, jest łysy, a człowiek, który ma $(n+1)$ włosów na głowie, nie jest łysy" nie jest prawdziwe;

3. Zdania posiadające formę klasycznych tautologii pozostają tautologiami nawet wtedy, gdy zmienne zdaniowe zastępujemy zdaniami nieostrymi;

${ }^{27}$ Przykład został przytoczony za: K. Misiuna, dz. cyt., s. 135-136. 
4. Dwa zdania sprzeczne, zawierające predykat nieostry, orzekany o przedmiocie należącym do obszaru niezdeterminowania tego predykatu, nie pociągają dowolnego zdania;

5. Teoria pojęć nieostrych powinna respektować fakty dotyczące językowej komunikacji ${ }^{28}$.

Opisywane zjawisko nieostrości można uchwycić z perspektywy słuchacza i obserwatora. Słuchacz otrzymuje komunikaty w formie zdań, które może określić za pomocą klasycznej logiki; obserwator zaś może spotkać się co najmniej z dwoma zdaniami, które mogą być ze sobą sprzeczne. Należy w tym miejscu zwrócić uwagę, że istnieje różnica między zdaniami będącymi zarazem prawdziwymi i fałszywymi oraz zdaniami nieposiadającymi żadnej wartości logicznej. Te drugie nie dostarczają nam bowiem żadnej informacji, gdyż nie jesteśmy w stanie określić ich prawdziwości, a co za tym idzie, tego, czy wnoszą one jakieś dane do opisu rzeczywistości. Tego typu wyrażenia nie są wartościowane w kontekście terminów logicznych, ale w terminach wartości mających charakter epistemiczny.

\subsection{Semantyka superwaluacyjna $\mathrm{w}$ zestawieniu z semantyką subwaluacyjną}

Zanim przejdziemy do rozważań na temat samej teorii krat, warto poświęcić trochę uwagi istotnemu dla tej kwestii zagadnieniu, a mianowicie zestawić ze sobą semantykę superwaluacyjną z subwaluacyjną, które bardzo dużo czerpią z omawianego wcześniej zjawiska nieostrości.

Za Danielem Hyde'em możemy stwierdzić, że semantyka subwaluacyjna, podobnie do semantyki superwaluacyjnej, korzysta z pojęcia dopuszczalnej precyzacji ${ }^{29}$. Jednak, jak to zaznacza Misiuna,

\footnotetext{
${ }^{28}$ Tamże, s. $136-137$.

${ }^{29}$ Zob. tamże, s. 147 oraz D. Hyde, „From heaps and gaps to heaps of gluts", Mind, 106 (1997), s. 641-661.
} 
na gruncie semantyki subwaluacyjnej przypadki graniczne, czyli przedmioty z obszaru niezdeterminowania predykatu nieostrego, traktowane są jako takie, o których dany predykat jest orzekany i zarazem nie jest orzekany ${ }^{30}$.

Warto powrócić do przykładu z wcześniejszych rozważań, a mianowicie: jeżeli przedmiot $a$ rozpatrzymy w kategorii niezdeterminowania przez predykat ,jest różowy”, to w obrębie semantyki subwaluacyjnej zdania „a jest różowy” i „a nie jest różowy” można uznać za prawdziwe, co daje wniosek, że zdanie „a jest różowy" jest zarazem prawdziwe i nieprawdziwe. Gdy chodzi o semantykę superwaluacyjną, to zdanie nieostre jest prawdziwe, a raczej superprawdziwe, gdy każda dopuszczalna jego precyzacja określa je mianem prawdziwego. Tu natomiast prawdziwość zdania nieostrego możemy określić przy jego pewnej precyzacji, którą dopuścimy ${ }^{31}$. Rozumienie prawdziwości (superprawdziwości) w semantyce superwaluacyjnej wiąże się z tym, że ta prawdziwość nie jest zależna od tego lub innego znaczenia, które zostaje narzucone $^{32}$. W semantyce subwaluacyjnej mamy do czynienia ze zjawiskiem zgoła przeciwnym, ponieważ to, czy zdanie będzie prawdziwe czy też nie, zależeć będzie w dużej mierze od tego, w jaki sposób sprecyzujemy nieostry predykat. Pojęcie prawdy w rozumieniu subwaluacyjnym będzie niejako kontrastować z naszym przekonaniem o tym, jak wygląda obiektywna prawda. Biorąc pod ogląd logikę czterowartościową na bazie podwójnej kraty FOUR $^{33}$, da się zauważyć, że zdanie, które wydaje się być prawdziwe przy pewnej precyzacji, a fałszywe przy innej, traktujemy jako zdanie, które może być interpretowane w kontekście epistemicznego bycia znanym jako prawdziwe i bycia znanym jako fałszywe. Natomiast gdy operujemy semantyką subwaluacyjną, możemy otrzymać interpretację nieintuicyjną, czyli taką, iż zdanie

\footnotetext{
${ }^{30}$ K. Misiuna, dz. cyt., s. 147.

${ }^{31}$ Zob. tamże oraz D. Hyde, dz. cyt., s. 647.

${ }^{32}$ Zob. K. Fine, „Vagueness, truth and logic”, Synthese, 30 (1975), s. 278.

${ }^{33}$ Logice tej poświęcony został cały podrozdział 2.3.
} 
może być zarazem prawdziwe i fałszywe ${ }^{34}$. Inną wadą semantyki subwaluacyjnej może być zjawisko niewystępowania klasycznej konsekwencji właśnie tam, gdzie wydawałaby się ona rzeczą najbardziej konieczną i podstawową. W semantyce superwaluacyjnej relacja konsekwencji zachowuje swoją superprawdziwość. Ale jeśli jakieś zdanie może być w jednym przypadku prawdziwe, a w innym fałszywe, to tym samym nie może ono być superprawdziwe. Jednak zasada niesprzeczności dla tych dwóch zdań zawsze będzie prawdziwa, a więc będzie superprawdziwa. Omawiany przykład pokazuje klasyczną niedysjunktywność superprawdziwości. Te i wcześniejsze rozważania doprowadziły nas do czterowartościowej logiki Belnapa opracowanej w 1977 r. ${ }^{35}$

\subsection{Logika czterowartościowa na bazie kraty FOUR}

Logika czterowartościowa Belnapa, aby móc pełnić rolę semantyki pojęć nieostrych, musi zostać rozszerzona i zmodyfikowana. Logika ta, oparta na kracie podwójnej FOUR, bywa nazywana właśnie logiką FO U R ${ }^{36}$. Reprezentuje ją schemat Haasego ${ }^{37}$ :

\footnotetext{
${ }^{34}$ Zob. K. Misiuna, dz. cyt., s. 147. Zjawiska opisywane w tym rozdziale będą łatwiejsze do zrozumienia po lekturze rozdziału 2.3, w którym to większość pojęć zostaje zdefiniowana.

35 Zob. tamże, s. 137-138.

${ }^{36}$ Zob. M. Fitting, „Bilattices and the theory of truth”, Journal of Philosophical Logic, 18 (1989), s. 229.

${ }^{37}$ Zob. tamże.
} 


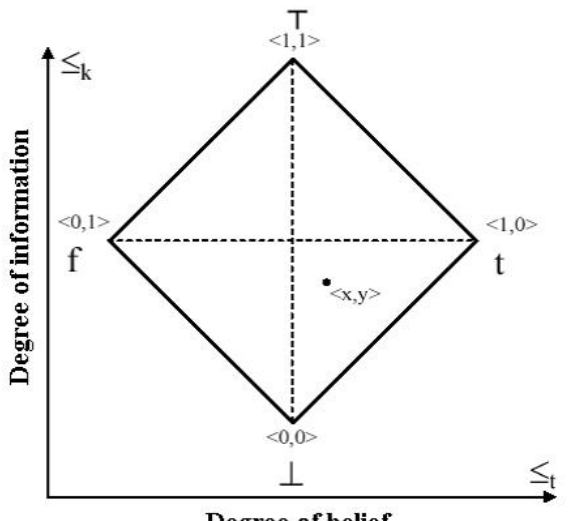

Degree of belief

gdzie:

1) $t$ reprezentuje prawdę;

2) $f$ reprezentuje fałsz;

3) $T$ reprezentuje zarazem prawdę i fałsz;

4) $\perp$ nie reprezentuje ani prawdy, ani fałszu.

Pierwszy z porządków w podanym schemacie kraty FOUR przedstawia miare prawdziwości (degree of belief), drugi zaś miarę wiedzy lub informacji (degree of information). Uwzględniając porządek prawdy, $t$ przysługuje wartość największa, zaś $f$-najmniejsza, lecz gdy chodzi o $T$ i $\perp$, są to wartości nieporównywalne i pośrednie. Natomiast ze względu na porządek wiedzy, $T$ przypisujemy wartość najmniejszą zaś $\perp$ najmniejszą, a $t$ i $f$ są elementami nieporównywalnymi. Biorąc pod uwage oba te porządki, otrzymujemy dwie kraty zupełne. Nie każda jednak krata podwójna jest kratą logiczną. W przypadku kraty logicznej zauważamy sprawdzalność danego twierdzenia: „Każda dystrybutywna krata podwójna może być przekształcona w logiczną kratę podwójną, chociaż nie każda krata logiczna jest dystrybutywna" 38 .

${ }^{38}$ O. Arieli, A. Avron, „Bilattices and paraconsistency”, [w:] Frontiers of paraconsistent logic, red. D. Batens, Baldock 2000, s. 11-28. cyt. za: tamże, s. 21 . 
Mając daną podwójną kratę logiczną, jesteśmy w stanie zdefiniować relacje konsekwencji ${ }^{39}$, gdy przyjmiemy jako wartości desygnowane elementy filtra pierwszej klasy, czyli jej niepustego podzbioru zawierającego elementy $x$ i $y$, będącego elementami tego podzbioru, oraz wszystkie relacje dla podwójnej kraty również będące elementami tego podzbioru. Taka krata FOUR posiada dokładnie jeden zbiór wartości desygnowanych $\{T, t\}$, gdzie $t$ oznacza wartość prawdy, a T jest wartością epistemiczną, która „jest znana jako prawdziwa i jest znana jako fałszywa" ${ }^{40}$. Pozostałe wartości to: fałsz - $f$ - oraz wartość symbolizowana przez $\perp$, która jest również interpretowana epistemicznie jako „nieznana jako prawdziwa i nieznana jako fałszywa" ${ }^{41}$.

Jeżeli w naszym wartościowaniu przyporządkujemy każdej formule atomowej wartościowanie $\perp$, to otrzymamy wartościowanie w każdej formule postaci $\perp$. Doprowadzi nas to do wniosku, że w logice krat podwójnych nie obowiązują tautologie. Co za tym idzie, nie działa prawo wyłączonego środka. W związku z tym „nie możemy zdefiniować implikacji w terminach alternatywy i negacji, ponieważ $p \rightarrow p$ okazałoby się wtedy formułą przyjmującą wartość $\perp$ w przypadku gdy p przyjmowałoby wartość $\perp$ i przyjmiemy symbol $\Rightarrow$ jako implikację dla kraty podwójnej. Tę możemy zdefiniować za Arielim i Avronem następująco:

$a \Rightarrow b=t$, jeśli $a$ nie jest wartością desygnowaną, $a \Rightarrow b=b$, w wypadku gdy $a$ jest wartością desygnowaną ${ }^{42}$.

\footnotetext{
${ }^{39}$ Definicja relacji konsekwencji: (za: J. Malinowski, „Logiki niemonotoniczne", Przeglad Filozoficzny, vol. 1, 21 (1997), s. 35.) Wielu logików zamiast pojęcia operacji konsekwencji woli używać pojęcia relacji logicznej konsekwencji, to znaczy relacji pomiędzy zbiorami zdań a zdaniami, spełniającej warunki odpowiadające w naturalny sposób warunkom refleksywności, idempotentności i monotoniczności. Pojęcia relacji i operacji logicznej konsekwencji są nawzajem definiowalne w sposób opisany następującym wzorem: $P \in C_{\vdash}(X) \Leftrightarrow X \vdash_{C} P$.

${ }^{40}$ K. Misiuna, dz. cyt., s. 21.

${ }^{41}$ Tamże.

${ }^{42} \mathrm{O}$. Arieli, A. Avron, „The value of four values”, Artificial Intelligence, 102 (1998), s. 97-141.
} 
Kraty podwójne to struktury algebraiczne, które możemy zastosować nie tylko w rozważaniach o teoriach rozumowań niemonotonicznych ${ }^{43}$. Teoria krat odsyła nas do wspomnianej już czterowartościowej logiki Balnapa, który jako pierwszy stworzył logikę opartą na dwóch kratach: pierwszej mierzącej prawdziwość, którą oznaczał jako L4, i drugiej zawierającej porządek, który mierzył wiedze lub informację, i oznaczał ją symbolem $A 4^{44}$. Szczególną rolę wśród krat podwójnych pełni owa krata FOUR, której rolę można porównać do roli kraty klasycznej, dwuelementowej w algebrze booleowskiej ${ }^{45}$. Podwójna krata FOUR może w swojej strukturze reprezentować inne logiki oparte na innych podwójnych kratach oraz można ją uznać za strukturę dostarczającą aparatury pojęciowej w klasycznych, niemonotonicznych i parakonsystentnych ${ }^{46}$ rozumowaniach $^{47}$.

Po zaprezentowaniu i omówieniu działania teorii podwójnej kraty FOUR, warto przyjrzeć się, celem wyciągnięcia pełniejszych wniosków, zastosowaniu tejże teorii w zestawieniu z innymi, wcześniejszymi koncepcjami, takimi jak np. logiki modalne, wielowartościowe, jednocześnie zwracając uwage na dotychczasowe rozumowania wydarzeń przyszłych. Możliwości stosowania teorii krat będą łatwiejsze do zrozumienia dzięki omówieniu pewnych jej struktur, używanych do analizy zdania języka naturalnego, a bez których logika oparta na podwójnej kracie FOUR nie istniałaby. Są to m.in. relacja konsekwencji w ujęciach różnych logik zajmujących się wydarzeniami przyszłymi, a także semantyka superwaluacyjna, na obszarze której wyrosła teoria krat.

\footnotetext{
${ }^{43}$ Zob. M. Fitting, „Kleene's logic generalized”, Journal of Logic and Computation, 1 (1990), s. 797-810 oraz tenże, „Kleene's three-valued logics and their children", Fundamenta Informaticae, 20 (1994), s. 113-131.

${ }^{44}$ Zob. K. Misiuna, dz. cyt., s. 23. Trochę inaczej motywuje wprowadzenie czterech wartości M. Dunn w artykule „Intuitive semantic for first-degree entailments and coupled trees", Philosophical Studies, 29 (1976), s. 149-168.

${ }^{45}$ Zob. O. Arieli, A. Avron, dz. cyt., s. 131-132.

${ }^{46}$ Najprościej i najbardziej ogólnie rzecz ujmując są to logiki w których pomija się prawo niesprzeczności.

${ }^{47}$ Zob. K. Misiuna, dz. cyt., s. 23.
} 


\section{Praktyczne zastosowanie teorii krat}

\subsection{Dotychczasowe rozumowania wydarzeń przyszłych}

Po wniosku wyciągniętym z części pierwszej niniejszego artykułu - że wydarzeń przyszłych nie da się opisać za pomocą logiki klasycznej - warto w tym miejscu omówić pokrótce kilka koncepcji mających na celu stworzenie narzędzi do analizy tychże wydarzeń. Pomysły te wydają się mniej użyteczne od teorii krat, w zakresie ich obowiązywania, ale posiadają narzędzia, z których możemy korzystać przy stosowaniu teorii krat.

Jednym z wielu ciekawych zjawisk jest tzw. logika temporalna, będąca jednocześnie poddziedziną logiki modalnej. Autorem logiki temporalnej jest Artur Prior, który wprowadził określenia dla czasowników wyrażających czas przeszły i przyszły, a które to mogą być odczytane i zinterpretowane jako operatory modalne postaci: „co najmniej raz w przeszłości” $(P)$ oraz „co najmniej raz w przyszłości" $(F)^{48}$. Na etapie dzisiejszego rozumowania jesteśmy w stanie zakwestionować tezę, że czasowniki odnoszące się do przeszłości czy przyszłości mogą się zachowywać jako operatory Priora ${ }^{49}$. W przypadku czasów gramatycznych naszego języka naturalnego mamy do czynienia z cechami wyrażeń okazjonalnych, których nie sposób znaleźć w przypadku operatorów $P$ i $F$. W języku naturalnym czasowniki mówiące zarówno o przeszłości, jak i o przyszłości, odsyłają nas do momentów czasowych, w których da się zauważyć określenia, które są relatywne do chwili wypowiedzi ${ }^{50}$. Jeśli chodzi o logikę temporalną, w której struktura złożona jest z niepustych momentów czasowych $T$, to jest ona uporządkowana za pomocą relacji dwuczłonowej „wcześniej niż”, którą

\footnotetext{
48 Tamże, s. 154.

49 Zob. J. Van Benthem, „Temporal patterns and modal structure”, Logic Journal of the IGPL, 7 (1999), s. 16.

${ }^{50}$ Zob. H. Kamp, U. Reyle, From discourse to logic. Introduction to modeltheoretic semantics of natural language, formal logic and discourse representation theory, Dordrecht 1993, s. 497.
} 
symbolicznie można przedstawić jako „," $<51$. Cechy tej relacji to zwrotność, przechodniość i liniowośćc ${ }^{52}$, gdzie liniowość nie jest respektowana jako logika temporalna w przypadku języka jakim jest np. programowanie ${ }^{53}$.

Biorąc również pod uwagę aspekt natury filozoficznej, będziemy skłonni liniowość zastąpić nieliniowościąa ${ }^{54}$. Zastanawiano się nad tym w kontekście indeterminizmu w odniesieniu do wydarzeń przyszłych. Jeżeli chodzi o nieliniowość, to pociąga ona za sobą fakt, że dany moment w czasie t posiada różne możliwości, które moga nastąpić po nim w przyszłości.

Te alternatywne możliwości rozumiane są nie jako możliwości wynikające z braku naszej wiedzy w momencie $t$ co do tego, co nastąpi w przyszłości, lecz jako ontologiczne cechy samego czasu, od których zależą wartości logiczne zdań czasowych. Intuicyjne zdania przygodne o zdarzeniach przyszłych różnią się od wielu innych zdań oznajmujących tym, że ich wartość logiczna nie jest znana w momencie wypowiedzi ${ }^{55}$.

Na podstawie tego rozumowania można wyciągnąć wniosek, że wartość logiczna zdania przed samym dokonanym zdarzeniem jest niemożliwa do określenia. Cytowana już kilkukrotnie Krystyna Misiuna przywołuje w swojej pracy, zatytułowanej Pojęcie prawdy w języku naturalnym, przykład z rzutem monetą. Wartość logiczna przykładowego zdania: „Wypadnie orzeł” nie może być określona aż do momentu rzutu. Choć wartość logiczna tego zdania o znaczeniu przygodnym nie jest znana we wcześniejszym momencie $t$, nie musi z tego wynikać, że $\mathrm{w}$ momencie $t$ takie zdanie nie

${ }^{51}$ K. Misiuna, dz. cyt., s. 155.

${ }^{52}$ Zob. tamże.

${ }^{53}$ Zob. C. Stirling, „Modal and temporal logics”, [w:] Handbook of logic in computer science, vol. 2, red. S. Abramsky, Oxford 1992.

${ }^{54}$ Zob. R. Thomason, „Indeterminist time and truth-value gaps”, Theoria, 36 (1970), s. 246-281 oraz tenże, "Combinations of tense and modality", [w:] Handbook of philosophical logic, vol. 2, (red.) D. Gabbay, Dordrecht 1984, s. $135-165$.

${ }^{55}$ K. Misiuna, dz. cyt., s. 156. 
ma wartości logicznej. W różnych teoriach da się zauważyć różny stosunek do powyższego faktu ${ }^{56}$.

Obok logiki temporalnej, inną semantyką, która z kolei odwołuje się do nielinearnych systemów relacyjnych, jest tzw. teoria ockhamistyczna ${ }^{57}$. Teoria ta ma na celu:

1. wyjaśnienie naszych braków w wiedzy co do wartości logicznej zdań przygodnych w momencie wcześniejszym niż $t$;

2. wyjaśnienie posiadania danej wartości logicznej już w samym momencie $t^{58}$.

W tejże semantyce zbiór tautologii opartych na operatorach $P$ i $F$ pokrywa się z tautologiami zbioru systemu linearnego. Podobnie ma to miejsce w przypadku relacji konsekwencji, która pokrywa się z odpowiadającą jej relacją i występuje w modelach linearnych ${ }^{59}$. Semantyka ta opisuje klasyczną wartość logiczną za pomocą formuły z operatorem czasu przyszłego w momencie wcześniejszym, a - jak pisze Misiura

co za tym idzie, na gruncie tej teorii, wypowiedzi o przyszłych zdarzeniach przygodnych mają klasyczną wartość logiczną w momencie wypowiedzi, natomiast nasz brak wiedzy we wcześniejszym momencie czasu co do tego, jaka to jest wartość, związany jest z tym, że nie wiemy w momencie wcześniejszym, która gałąź ${ }^{60}$ będzie zaktualizowana ${ }^{61}$.

W logice ockhamistycznej istnieje możliwość rozróżnienia zdań wyrażających zdarzenia przygodne, w których nie znamy wartości logicznej zdania w samym momencie wypowiadania go oraz takie, w których tą wartość jesteśmy już w stanie określić. Gdy mówimy

56 Zob. tamże.

57 Zob. A. Prior, Past, present and future, Oxford 1967, s. 122-127.

58 Zob. K. Misiuna, dz. cyt., s. 157.

59 Zob. R. Thomason, dz. cyt., s. 144.

60 Gałąź, o której pisze K. Misiura, to odpowiedź na pytanie: czy w rzucie otrzymamy orzełka czy reszkę?

${ }^{61}$ K. Misiuna, dz. cyt., s. 157. 
o tych drugich, to możemy zdefiniować je jako operator L, który jest określeniem zdania postaci: „,jest nieuchronne, że” ${ }^{62}$.

Inny punkt widzenia na zdarzenia przygodne otrzymamy, gdy połączymy ową teorię ockhamistyczną z semantyką superwaluacyjna ${ }^{63}$. W takim kontekście zdaniom o przyszłych wydarzeniach przygodnych we wcześniejszym momencie $t$ nie przysługuje klasyfikacja prawdy czy fałszu jakiegoś sądu. W powyższym modelu wykorzystanie koncepcji superwaluacyjnej polega na tym, że „prawdziwość (fałszywość) formuły utożsamia się tu z prawdziwością (fałszywością) przy wszystkich klasycznych wartościowaniach. Natomiast formuły, które przy wszystkich klasycznych wartościowaniach nie są ani prawdziwe, ani fałszywe, pozostaja niezdefiniowane. W tym przypadku klasyczne wartościowania przyporządkowują formule klasyczną wartość logiczną relatywnie do modelu, momentu czasowego i gałęzi czasu" 64 .

Oprócz tych trzech omówionych teorii ${ }^{65}$, warto zwrócić uwage na dwie równie ważne teorie jednakowoż nasycone brakami w swoich rozumowaniach. Chodzi mianowicie o teorię Peirce'a mówiącą, że ,zdania o przyszłych wydarzeniach przygodnych są fałszywe w dowolnym wcześniejszym momencie czasu" 66 oraz trójwartościową logikę Łukasiewicza, utrzymującą, że „zdania o przyszłych zdarzeniach logicznych posiadają trzecią wartość logiczną, różną od prawdy i fałszu" ${ }^{67}$, którą oznacza się, obok klasycznych (0) i (1), jako 1/2. Ta trzecia wartość zakłada możliwość wystąpienia zarówno prawdy, jak i fałszu.

\subsection{Relacja konsekwencji a wydarzenia przyszłe}

Na podstawie omówionej już (przy okazji przedstawiania kraty podwójnej) relacji konsekwencji warto zwrócić uwagę na jej od-

\footnotetext{
62 Tamże.

63 Zob. R. Thomason, dz. cyt., s. 145.

${ }^{64}$ K. Misiuna, dz. cyt., s. 159.

65 Semantyka superwaluacyjna, ockhamistyczna i linearna.

${ }^{66}$ K. Misiuna, dz. cyt., s. 160.

67 Tamże.
} 
powiednik w rozumowaniach o wydarzeniach przyszłych. Zdania o wydarzeniach przyszłych, jak to wykazano wyżej (2.1.), były rozumiane różnie, ale zasadniczo można by było przypisać je do dwóch grup, gdzie jedne będą respektować tautologie linearnej logiki temporalnej, a drugie tych tautologii respektować nie będą. Da się tylko stwierdzić, że w obu grupach, „tautologie te reprezentuja zdania intuicyjnie uznawane za prawdziwe" 68 . Bardziej korzystny wydaje się być w tym wypadku wybór grupy pierwszej wśród tautologii, ze względu na ich korzystanie z linearnej logiki temporalnej. Ale czy wszystkie tautologie są w rzeczywisty sposób respektowane przez potoczne rozumienie przygodnych wydarzeń? Przykład podaje Misiuna, mówiąc, że

w linearnej logice temporalnej formuła $F_{p} \wedge F_{q}$ nie jest logicznie równoważna z formułą $F(p \wedge q)$, a co za tym idzie, $F(p \wedge q)$ nie wynika logicznie z $F_{p} \wedge F_{q}{ }^{69}$.

Dzieje się tak dlatego, że zdanie $p$ nie musi wcale wyrażać tego samego czasu co $q$, więc nie musi zaistnieć fakt, że i zdanie $p$, i zdanie $q$ będzie musiało być w czasie przyszłym. Chociaż da się to powiedzieć o koniunkcji samych tych zdań, a nie ich wyrażeń przyszłych. I dalej:

Kontrmodelem pokazującym, że nie zachodzi powyższa relacja konsekwencji, jest sytuacja, w której $p$ jest prawdziwe w pewnym momencie czasu w przyszłości, a $q$ jest prawdziwe $\mathrm{w}$ innym momencie czasu w przyszłości. Zatem nie istnieje ten sam moment w przyszłości, w którym prawdziwe jest $p$ i zarazem $q^{70}$,

gdyż niemożliwe jest, aby zdania takie były w jednym momencie o tej samej wartości.

Warto zwrócić uwagę, analizując ów kontrmodel pod kątem pokrycia się z rzeczywistością, gdy mówimy np. o wspominanym

\footnotetext{
${ }^{68}$ Tamże, s. 162.

${ }^{69}$ Tamże.

${ }^{70}$ Tamże.
} 
już przykładzie z rzutem monetą. Logiczna zasada konsekwencji, w świetle kontrmodelu, sugerowałaby, że po pierwszym rzucie monetą, w którym wypadłby orzełek, to w drugim bylibyśmy zobligowani do otrzymania reszki, a tak przecież być nie musi. Przykład ten pokazuje bardzo jasno, że w naszym potocznym języku relacja konsekwencji może być nieco inaczej pojmowana niż w temporalnej logice linearnej. Można też wyciągnąć następujący wniosek, że jest możliwe wyrażenie sądu czy zdania o zdarzeniu przygodnym „,jest prawdziwe” czy „, jest fałszywe”, bez uwzględniania momentu czasowego. W każdym z przypadków będzie możliwość jasnego stwierdzenia tego sądu, mimo, że wartość logiczna zdania nie jest znana zanim nastąpi właściwy moment czasowy. Dlatego możemy także stwierdzić, że zdanie o wydarzeniu przygodnym jest superprawdziwe, jeśli spełni się jego praw d zi wość lub jest superfałszywe, gdy z kolei okaże się, że owo zdarzenie nie będzie miało miejsca ${ }^{71}$. Trzeba jednak założyć, że osobno podkreślimy także naszą wiedzę na temat tego oto zdarzenia.

Misiuna słusznie zauważa, że powinniśmy wystrzegać się analizy zdań, które zawierają w wyrażanym języku naturalnym sformułowania bezsensowne, i jako przykład podaje zdanie: „Największa liczba rzeczywista będzie sumą liczb pierwszych" ${ }^{\prime 2}$. Zdanie to tylko z pozoru jest zdaniem o wydarzeniu przyszłym i równie pozornie sugeruje możliwość doszukiwania się w nim wartości logicznej. Pozostaje ono bezsensowne, gdyż nie istnieje największa liczba rzeczywista i nie można w tym przypadku określić fałszywości ani tym bardziej prawdziwości owego zdania.

\subsection{Zestawienie teorii krat z wcześniejszymi koncepcjami}

Poddajmy refleksji dwa zdania mówiące o wydarzeniu przyszłym: (i) „W tym rzucie wypadnie orzeł” oraz (ii) „Orbita lecącej komety będzie się znajdowała w pobliżu Ziemi" ${ }^{73}$. Zdanie

\footnotetext{
${ }^{71}$ Zob. tamże.

${ }^{72}$ Tamże, s. 163.

${ }^{73}$ Przykłady do analizy podaje za: tamże, s. 176.
} 
(i) mówi nam o zdaniu przygodnym, co do którego zaistnienia nie mamy pewności, zaś zdanie (ii), w świetle dzisiejszej nauki, sugeruje - chciałoby się rzec - jego pewność. Warto to zdanie przeanalizować na gruncie omawianych wcześniej koncepcji semantycznych, będących zarazem „odmiennymi teoriami empirycznej przygodności" 74 .

Patrząc z perspektywy semantyki superwaluacyjnej zdanie (i) jest niezdefiniowane $\mathrm{w}$ dowolnym momencie przed samym rzutem, zaś zdaniu (ii) musielibyśmy przypisać operator postaci „jest nieuchronne to, że". W koncepcji Pierce'a zdanie (i) jest fałszywe, gdyż nie jest zobligowane do spełnienia danego warunku, a zdanie (ii) będzie prawdziwe, o ile jest konieczne. $\mathrm{W}$ teorii ockhamistycznej zdanie (i) może być albo prawdziwe, albo fałszywe, w zależności od gałęzi czasu, a prawdziwość zdania (ii) jest również uzależniona od operatora „jest nieuchronne”, jeśli zaś chodzi o koncepcję Eukasiewicza, to zdanie (i) ma w dowolnym momencie przed rzutem trzecią wartość logiczną 1/2, zaś zdanie (ii) otrzyma walor prawdziwości.

Jeśli zaś zdanie (i) i (ii) poddamy analizie semantyki preferencyjnej na bazie podwójnej kraty FOUR, która była omawiana w rozdziale drugim, to dojdziemy do następujących wniosków: wartość prawdziwości zdania (i) uzależnimy od wartościowania przez klasyczną funkcję wartościowania, wówczas zdanie to może jednocześnie „mieć wartość epistemiczną: z n a n e jako prawdziwe i znane jako fałszywe $(T)$ lub ani znane jako prawdziwe, ani z n ane jako fałszywe $(\perp)^{75}$. Jeżeli zdanie (ii) poprzedzimy operatorem „,jest znane to, że", to przy takim rozumieniu będziemy mogli stwierdzić jego prawdziwość, dlatego że semantyka ta uwzględnia słabszy aspekt operatora „,jest znane to, że”. Przy powyższym rozumieniu możemy z łatwością dostrzec różnicę między zdaniami (i) i (ii), jakiej można się było spodziewać. Zaś gdy operatorowi ,,jest znane to, że" nadamy mocniejszy sens poprzez przypisanie go do zdania (i), to uznamy owe zdanie (i) za fał-

\footnotetext{
${ }^{74}$ Tamże, s. 177.

${ }^{75}$ Tamże.
} 
szywe, dlatego, że sama intuicja podpowie, iż nie jest znane to, że w momencie rzutu otrzymamy orzełka czy reszkę. Przeciwną sytuację mamy natomiast $\mathrm{w}$ analizie zdania (ii), które to zdanie $\mathrm{w}$ języku naturalnym ma już zupełnie inne znaczenie ${ }^{76}$.

Jeśli chodzi o ogólną charakterystykę rozumowań o wydarzeniach przyszłych przygodnych, to istotną uwagą wydaje się być spostrzeżenie, że możemy dojść do sprzecznych przewidywań. Znaczy to tyle, że owa relacja konsekwencji doprowadzi nas do swojego podstawowego warunku, a mianowicie, że powinna być parakonsystentna $^{77}$. Ponadto, żadna z koncepcji semantycznych „nie posiada środków umożliwiających adekwatne ujęcie sprzecznych przewidywań" 78 . W naszych rozważaniach nie jesteśmy w stanie zlikwidować wszystkich sprzeczności, lecz tylko je zminimalizować, a ta czynność będzie przemawiać za kolejną cechą niemalże wszystkich rozumowań potocznych, zwłaszcza tych wyrażonych za pomocą przyszłych wydarzeń przygodnych, a mianowicie za jej niemonotonicznością. Wraz ze wzrostem informacji zauważymy, że niektóre wnioski należy po prostu odrzucić, gdyż nowe informacje moga być w całkowitej albo częściowej sprzeczności z zaprezentowanymi wcześniej efektami naszych rozważań ${ }^{79}$.

Konkluzja z niniejszych analiz nasuwa się sama: wnioski nie wynikają z przesłanek $\mathrm{w}$ ramach relacji konsekwencji, a dana relacja omawianych zdań jest niemonotoniczna i jednocześnie parakonsystentna, ponieważ ukazuje, iż dowolny wniosek nie wynika ze zbioru, który nie opiera się na klasycznym modelu. Dlatego to właśnie „preferencyjna relacja konsekwencji oparta na kracie podwójnej FOUR, będąca teoretycznym modelem rozumowań o przyszłych zdarzeniach przygodnych, spełnia - naszym zdaniem - warunki konieczne, których spełnienia oczekiwaliśmy od relacji konsekwencji dla tego typu rozumowań" 80 .

76 Zob. tamże, s. 177-178.

77 Termin wyjaśniony w przypisie 44 .

${ }^{78}$ K. Misiuna, dz. cyt., s. 178.

79 Zob. tamże.

80 Tamże, s. 179. 


\section{Zakończenie}

Żadna z dotychczasowych koncepcji w historii logiki nie wyczerpała w zupełności tematu jej wielowartościowości. Logika czterowartościowa oparta na bazie podwójnej kraty FOUR omawiana przeze mnie $\mathrm{w}$ tym artykule, również pozostawia wiele otwartych furtek, dzięki którym będzie się ona mogła rozwijać i doprowadzić do jeszcze bardziej zadowalających efektów.

W swoich rozważaniach rekonstrukcyjnych próbowałem pokazać, że właśnie owa krata FOUR jest obecnie najlepszą i najdokładniejszą w opisie koncepcją logiczną, dzięki której jesteśmy w stanie analizować wydarzenia mające mieć miejsce w przyszłości. Krata podwójna wydaje się być trafną odpowiedzią na logiki klasyczne, które nie brały pod uwagę zdarzeń przyszłych, a także jest koncepcją mocniejszą niż wcześniejsze, które przysłużyły się strukturze krat, dając jej bardzo wiele narzędzi, uzupełniając i ulepszając jej zakres oraz dokładność badań. Przedstawiłem klasyczne ujęcie prawdy w logice w systemie dwuwartościowym, wskazując jednocześnie na braki w klasycznej teorii. Kolejno zarysowałem wytworzenie się teorii krat, poprzez prezentację takich zjawisk jak nieostrość, subwaluację czy relację konsekwencji, skończywszy na wielu dwudziestowiecznych tworach logiki współczesnej, podejmujących w swoich badaniach podobne zagadnienia.

W swojej pracy wykazałem ponadto słuszność postawionej na początku tezy, że struktura kraty podwójnej pozwala na głębsze i dokładniejsze przybliżenie codziennego rozumowania, dając jego pełniejszy obraz.

Koncepcja tejże logiki czterowartościowej jest cennym zagadnieniem do dalszej pracy, ponieważ zostawiając pewne kwestie otwartymi, skłania do dalszej refleksji i głębszego jej przeanalizowania. $\mathrm{W}$ moim przekonaniu, może ona stać się bardzo cennym punktem wyjścia do stworzenia jeszcze bogatszej struktury, mogącej opisać, jeśli nie cały, to przynajmniej szerszy kontekst badanej przez nas rzeczywistości języka naturalnego, którym posługujemy się na co dzień. 


\section{Bibliografia}

1. Arieli O., Avron A., „Bilattices and paraconsistency”, [w:] Frontiers of paraconsistent logic, red. D. Batens, Baldock 2000.

2. Bach K., „Language, Logic and Form”, [w:] A Companion to Philosophical Logic, red. D. Jacquette, Oxford 2002.

3. Changizi M., „Vagueness and computation”, Acta Analytica, 14 (1999).

4. Fine K., „Vagueness, truth and logic”, Synthese, 30 (1975).

5. Fitting M., „Bilattices and the theory of truth”, Journal of Philosophical Logic, 18 (1989).

6. Fitting M., „Kleene's logic generalized”, Journal of Logic and Computation, 1 (1990).

7. Fitting M., „Kleene's three-valued logics and their children”, Fundamenta Informaticae, 20 (1994).

8. Haack S., „Logika modalna”, [w:] Filozofia logiki, red. J. Woleński, Warszawa 1997.

9. Haack S., „Niektóre pytania metafizyczne i epistemologiczne dotyczące logiki", [w:] Filozofia logiki, red. J. Woleński, Warszawa 1997.

10. Hyde D., „From heaps and gaps to heaps of gluts”, Mind, 106 (1997).

11. Kamp H., Reyle U., From discourse to logic. Introduction to modeltheoretic semantics of natural language, formal logic and discourse representation theory, Dordrecht 1993.

12. Malinowski G., Logiki wielowartościowe, Warszawa 1990. 
13. Malinowski J., „Logiki niemonotoniczne”, Przeglad Filozoficzny, vol. 1, 21 (1997).

14. Misiuna K., Pojęcie prawdy w języku naturalnym, Warszawa 2003.

15. Prior A., Past, present and future, Oxford 1967.

16. Stirling C., „Modal and temporal logics”, [w:] Handbook of logic in computer science, vol. 2, red. s. Abramsky, Oxford 1992.

17. Thomason R., "Combinations of tense and modality”, [w:] Handbook of philosophical logic, vol. 2, red. D. Gabbay, Dordrecht 1984.

18. Thomason R., „Indeterminist time and truth-value gaps”, Theoria, 36 (1970).

19. Tomasello M., „Reference: intending that others jointly attend", Pragmatics and Cognition, 6 (1998).

20. Tomasello M., „The human adaptation for culture”, Annual Reviews of Anthropology, 28 (1999).

21. Van Benthem J., „Temporal patterns and modal structure”, Logic Journal of the IGPL, 7 (1999).

\section{Abstract}

\section{Bilattices: An attempt to describe future events with the help of the tools of logic}

An unflagging interest in describing future events has continuously motivated investigations, particularly in the field of logic. 
Aristotle, universally acknowledged as the father of logic, proposed a set of certain bases from which we could depart with our investigations. However, these are tools in which, despite their great value, one can perceive certain shortcomings.

Over the centuries many attempts have been made to discover a means of describing any sentence, expressed in any grammatical form. One of these attempts is bilattice theory, through which it has been attempted to describe future events. This theory makes use of tools such as vagueness and different forms of semantics including subvaluationism and supervaluationism.

In lattice theory itself, the double lattice known as the FOUR lattice (four-valued bilattice logic) is directly employed.

After analyzing the structure of a given theory one may easily make use of it in practice, providing examples of its usage.

Keywords: two-valued logic, many-valued logic, expansion of classical logic, modal logic, semantic supervaluationism, semantic subvaluationism, the FOUR double lattice, Belnap's four-valued logic. 